This item was submitted to Loughborough's Research Repository by the author.

Items in Figshare are protected by copyright, with all rights reserved, unless otherwise indicated.

\title{
European Union financial integration, a geography perspective
}

PLEASE CITE THE PUBLISHED VERSION

https://doi.org/10.1111/gec3.12424

\section{PUBLISHER}

John Wiley \& Sons Ltd @ The Author, Geography Compass and John Wiley \& Sons Ltd

\section{VERSION}

AM (Accepted Manuscript)

\section{PUBLISHER STATEMENT}

This is the peer reviewed version of the following article: VAN MEETEREN, M., 2019. European Union financial integration, a geography perspective. Geography Compass, 13 (4), e12424, which has been published in final form at https://doi.org/10.1111/gec3.12424. This article may be used for non-commercial purposes in accordance with Wiley Terms and Conditions for Use of Self-Archived Versions

\section{LICENCE}

CC BY-NC-ND 4.0

\section{REPOSITORY RECORD}

Van Meeteren, Michiel. 2019. "European Union Financial Integration, a Geography Perspective”. Loughborough University. https://hdl.handle.net/2134/37535. 


\title{
European Union financial integration, a geography perspective
}

\section{Michiel van Meeteren, (m.van-meeteren@lboro.ac.uk)}

Loughborough University, School of Social Sciences, Geography and Environment

Vrije Universiteit Brussel, Department of Geography

This paper is forthcoming in Geography compass, please cite published version

Van Meeteren, M (2019) European Union financial integration, a geography perspective.

Geography Compass, DOI: 10.1111/gec3.12424

\begin{abstract}
During the last thirty years, the financial sectors of the different European Union member states have gradually coalesced toward operating in a single, integrated, European financial space. This paper analyses financial integration by chronicling the process from Jacques Delors' single market project until the recent Capital Markets Union. Drawing on geographical theories of space and scale, the paper collates the large interdisciplinary literature on financial integration with an emphasis on the work of financial geographers. The result is a distinctive geographical perspective on European financial integration intended to inform new rounds of empirical research.

Acknowledgements

A previous version of this paper was presented at the 2018 Global Conference in Economic Geography in Cologne. The paper's genesis owes much to the critical comments of Geography Compass' reviewers and Manuel Aalbers, David Bassens, Sabine Dörry, Callum Ward, Maelys Waïengnier, and the continuing discussions at the Financial Geography team at the Vrije Universiteit Brussel between 2016 and 2018. Research work on this paper was funded through FWO Research Grant G019116N.
\end{abstract}




\section{Introduction}

Financial integration should be seen as a multidimensional process that takes a group of economies from 'financial autarky' within their respective borders to a single financial market in which geography has become irrelevant. [...] If the world were to head for a single financial market, the concept of a single European financial market would eventually lose its relevance. (IMF economist Wim Fonteyne, 2007, p. 5, emphasis added).

Henceforth, we should not only speak of a European financial market, but of a genuine financial space [...]. Similarly, reinforced monetary coordination on the scale of the European Community is inscribed in the natural extension of European financial space. (European Commission president Jacques Delors, 1992 [1989], p. 155; translated from French, emphasis added).

The above statements about European financial integration express sharply different geographical imaginations (Lee, 2002). First, there is the IMF economist's perspective of space passively waiting to be eradicated by the market. Contrast this with Jacques Delors' narrative, where market making necessitates actively inscribing and producing EU material spaces. For him, transnational markets are social constructions that gain their vitality from their participating actors. Consequently, in Delors' worldview (Ross, 1995, p. 109), Europeanization entails actively 'reorganizing European space' (Delors 1992 [1988], p. 75) as the common market could not exist without deeper social ties between Europeans (Ross, 1995, pp. 120-121). This contrast between spatial imaginations illustrates that the economist view of the world of "angels dancing on heads of pins" (Lee 2002, p. 337) is incomplete and that Delors understood if the European project was to be successful, the deterritorialization that came with the single market always had to be coupled with reterritorialization (Brenner, 2004).

This paper recounts three decades of European financial integration from a financial geography perspective, where the production of space is as central as its eradication. At the start of the Delors Commission in 1985, the European Economic Community (EEC) comprised ten shielded national financial markets ${ }^{1}$ and the London based 'Euromarkets' (Mügge, 2006, p. 1005). In the ensuing three decades, these markets gradually coalesced into a new geographic formation, engulfing new member states in the process. Nevertheless, instead of spatial homogenization, financial integration

\footnotetext{
${ }^{1}$ The EEC member states in 1985 were: Belgium, Denmark, France, (West-)Germany, Greece, Ireland, Italy, Luxembourg, the Netherlands, and the United Kingdom. Portugal and Spain would join on January 1, 1986.
} 
exacerbated uneven development (Hadjimichalis, 2011). In the EU's power centres, this unevenness is often cast as a problem of the "arrow points to defective part" type (Engelen et al., 2011, p. 3). Uneven development allegedly results from insufficient integration rather than an effect of prior policy. This diagnosis is again indicative of an EU elite discourse of Europeanization through eradication of spatial difference, which Jensen and Richardson (2004) describe as 'monotopia'. Likewise, contemporary financial integration proposals such as Banking Union (Howarth \& Quaglia, 2016) and Capital Markets Union (Braun et al., 2018) are similarly imbued with monotopia, where more integration through eradicating geographical difference is cast as solution rather than part of the problem.

New challenges for European finance associated with Brexit and the rise of fintech (Cassis \& Wójcik, 2018; Hendrikse et al., 2018; Lavery et al., 2018) raise the need to recalibrate, chronicle, and theorize with a richer geographical imagination (Sokol, 2013). In order to chronicle concisely, this paper is selective. It analyses the Europeanization of finance from the EU perspective, without elaborating interdependencies with other scales. Moreover, it brackets the parallel development of monetary integration unless it directly impinges on financial integration. The paper first erects a theoretical framework that integrates perspectives from different disciplines under a financial geography umbrella. The subsequent main section sketches an EU financial integration timeline. For each five to seven year period, major EU policy initiatives and its interplay with the European financial sector are discussed. Afterwards, these findings are briefly corroborated with relevant aggregate statistics provided by the European Central Bank. In the conclusion, the attained overview is reinserted in wider debates in economic and financial geography.

\section{Making EU financial space}

Agnew and Corbridge (1995) argue how "mastering space" depends on a mixture of political geographies, geopolitical orders, and the international political economy. Their framework is based on Lefebvre's (1991 [1974]) production of space, where the interplay between "spatial practices", "representations of space" and "representational spaces" (Figure 1) is central. Spatial practices refer to the material spaces, circuits, and flows (Hudson, 2004) spun over the face of the earth that constitute economic production and social reproduction. Representations of space refer to how people make sense of spatial practices in language and reflect the geographies of the present that guide our commonsensical understanding of, and behaviour in, the world. Representational spaces are scenarios for future practices: imagined geographies of the future that inspire changes in the representation of space. (Agnew and Corbridge, 1995, p. 7). In Lefebvre's (1991 [1974]) schema, these three dimensions of space continuously influence one another. As capitalism expands, spatial 
practices are never fully grasped by their representations of space sparking tensions about continued accumulation. Representational spaces project an image of a future that can stabilize that tension. As the EU integrates, our geographical imagination of what kind of macro-region the EU is co-evolves (Lee, 1976; Taylor, 1991). Representational spaces depicting a more Europeanized future is what political geographers have called building geographies of EUrope (Clark \& Jones, 2008). These geographies depict imagined futures (Beckert, 2016) that can act as self-fulfilling prophecies. Once agents believe a certain future will come to pass, they will act according to that future expectation (idem) and contribute to bringing it into being. This is what in economic and financial geography is called "performativity" (see Barnes, 2008 for an introduction).

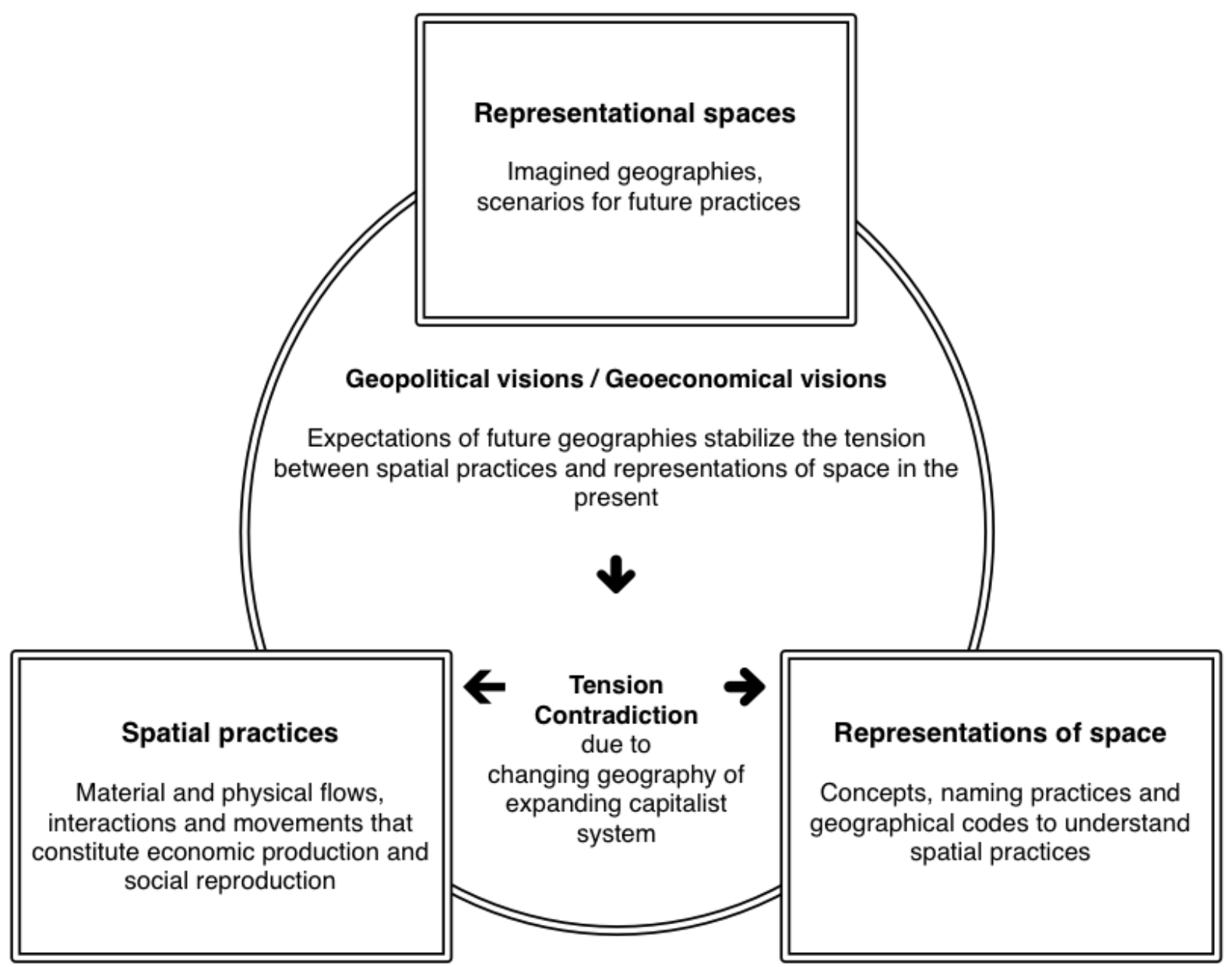

Figure 1. Mastering space, interpreting Agnew and Corbridge's (1995) Lefebvrian model.

Fligstein (2000) provides an actor perspective on Europeanization that accounts for this performativity of representational spaces. For Fligstein $(2000,26)$ Europeanization is "how EU political and legal projects have changed the way that people [and firms] within Europe, but outside the Brussels complex, have interacted over time". This leads to a spiralling interplay between increasing transnationalization of social interactions in the $\mathrm{EU}$ and institutionalization of these interactions on the European scale (Stone Sweet et al., 2001). Through transformations in practices, Europe as a lived 
experience changes and reaffirms the existence of the EU as a geographical scale (Rovnyi \& Bachmann, 2012), regardless whether that is evaluated positively or negatively. We shall see that European financial institutions have at times adjusted their behaviour to expectations raised in EU financial regulation policy cycles (Dixon, 2011; Dymski, 2012; Mügge, 2010). New acts of EU legislation are representations of space that signpost progress towards the representational space of a future EU. Gradually, finance-state interactions are "uploaded" (Mügge, 2010) to the EU scale, engendering a scalar fix (Jonas 1994; Smith 1995). The more institutions become reliant on the scale of the EU, the more it evolves from a space of engagement into a space of dependence, where the necessity to keep the scale stable to avert crises increases (Cox, 1998; Van Meeteren and Bassens, 2016).

The Europeanization of financial regulation is the historical outcome of a search for an "island of stability" (Bassens \& Van Meeteren, 2018; Leyshon \& Thrift, 1995; Swyngedouw, 2004) in an increasingly turbulent global financial environment. The EU scale has since its inception been a refuge for European nation states when they could no longer stabilize the contradictions of capitalism (Milward, 2000 [1992]). Since the 1970s, nation states particularly sought refuge to shield from, while also craving the benefits of, the increased proliferation of financial capital (French et al., 2011; Sokol, 2013). Creating this island of financial stability entailed keeping the volatility of a financialized global economy outside, and the benefits inside the EU's boundaries (Bassens \& Van Meeteren, 2018) .

A scalar fix is never mono-scalar, and the EU is but one scaffold in a scalar division of labour (Brenner 1998). The EU scale itself also has a variable geometry (Strubb, 1996) where EU jurisdiction does not have the same depth in each place. For instance, EU member states outside the Eurozone still have to adhere to Commission directives regarding financial market governance. Arbitrating this legal variable geometry produces its own lucrative financial geographies (Aalbers, 2018; Van Meeteren and Bassens, 2016). Moreover, the EU scale comprises different power centres: the European Commission, the European Council, the European Parliament and comitology procedures determine policy outcomes in interaction (Mamadouh and Van der Wusten, 2008; Quaglia, 2010a). Each of these centres articulates a different balance of power between member-state interests. Additionally, the EU's variable geometry interacts with regional and national institutional differences, while firms, markets and regulations rarely Europeanize in tandem within and across contexts (Aalbers, 2009a). Actors such as the European Central Bank (ECB) (Kalaitzake, 2018), the international Basel-based financial governance committees (Bieri, 2009), and the OECD and IMF (Abdelal, 2007) also impact the scalar division of labour. The result is a territorially variegated pattern (Peck \& Theodore, 2007) where the exact combination of spatial effects of the EU scale differ from place to place depending how scales are imbricated in situ (Brenner, 2009). Resultantly, when European financial integration intensifies, instead of homogenization, a changing geography of uneven development is 
set in motion interacting with the variegated pre-exiting pattern of spatial practices (Hadjimichalis, 1994; Hudson, 2003).

To retain focus in such a complex landscape, this paper reads EU financial integration anchored through the history of European Commission directives. A directive is binding regulation for member states but transposition in national law is member state responsibility (McCormick, 2008, p. 73). There is a time lag between directive adoption and the transposition deadline. A directive could be performative as expectations of EU futures might trigger anticipating action by market actors. Analysing the adoption and effects of different generations of financial integration directives is the main tool by which this paper probes the gradual Europeanization of finance.

\section{Conjunctures of European financial integration (1986-2017)}

Although the period since the 1970s exhibits increasing dominance of finance (French et al. 2011), 'conjunctures' are shorter-term periods that meaningfully subdivide this epoch (Bassens et al., 2013; Engelen et al., 2011; Van Meeteren \& Bassens, 2018). Conjunctures are fragile periods where specific financial sector business models align with the macroeconomic and regulatory context. The main financial integration initiatives have tended to follow policy cycles of five to seven years often coinciding with the succession of European Commissions. These define the conjunctures. The paper will chronologically describe five conjunctures: 1985-1992, 1992-2000, 2000-2007, 2007-2012 and 2012-2017. The relevant directives are summarized in Table 1.

\subsection{5-1992: The '1992' European relaunch}

In 1985, Europe's future looked bleak. The 1970s crisis had severely weakened member state economies and strategies to rejuvenate national industrial champions were failing. Moreover, Europe felt left behind by the high-tech innovation coming from California and Japan (Albert \& Ball, 1983). The Single European Act (1986) and the completing the internal market project (COM, 1985), commonly called "the 1992 project", were newly-minted Commission president Delors' opening bids to relaunch the EEC, the EU's predecessor (Sandholtz \& Zysman, 1989; Sadler, 1992; Van Apeldoorn, 2002), and turn the economic tide. Financial integration was regarded pivotal to the 1992 project. Europeanizing the financial sector had to deliver a significant amount of the projected growth (Cecchini, 1988; cf. Bieling, 2006, Chick \& Dow, 2012) and was considered a prerequisite for financing the Europeanization of other sectors (Leyshon \& Thrift, 1992; Llewellyn, 1992; Tickell, 1999). Additionally, the industrial policy paradigm was shifting whereby (financial) services were regarded a propulsive growth sector rather than merely auxiliary to (heavy) industry (Illeris, 1989). Lastly, the 
1986 London "big bang" (Leyshon \& Thrift, 1997) generated awe about the gains of a liberalized, technologically forward-looking financial services sector (Maes, 2007), spawning little big bangs across European financial centres (Moran, 1994).

Table 1. Key financial integration directives 1985-2017

\begin{tabular}{|c|c|c|c|c|}
\hline Directive Name & $\begin{array}{l}\text { Directive } \\
\text { number }\end{array}$ & $\begin{array}{l}\text { Date } \\
\text { adopted }\end{array}$ & $\begin{array}{l}\text { Date } \\
\text { transposed }\end{array}$ & Summary of goal/effect \\
\hline \multicolumn{5}{|c|}{ Conjuncture 1. 1985-1992: The "1992" European relaunch } \\
\hline Capital Markets Directive & $88 / 361 /$ EEC & 24/06/1988 & 01/07/1990 & $\begin{array}{l}\text { Abolished capital controls and } \\
\text { enshrined "freedom of capital" }\end{array}$ \\
\hline Second Banking Directive & $89 / 646 / \mathrm{EEC}$ & 15/12/1989 & 01/01/1993 & $\begin{array}{l}\text { Established home country } \\
\text { passport principle for banks }\end{array}$ \\
\hline Captial Adequacy Directive & $89 / 647 /$ EEC & 18/12/1989 & 01/01/1991 & $\begin{array}{l}\text { Regulated Basel I solvency } \\
\text { requirements }\end{array}$ \\
\hline \multicolumn{5}{|c|}{ Conjuncture 2. 1992-2000: The roaring nineties and the promise of globalization } \\
\hline Investment Services Directive & 93/22/EEC & $10 / 05 / 1993$ & $31 / 12 / 1995$ & $\begin{array}{l}\text { Established host country } \\
\text { passport principle for investment } \\
\text { firms }\end{array}$ \\
\hline \multicolumn{5}{|c|}{ Conjuncture 3. 2000-2007: Europe sinks in the age of market-based banking } \\
\hline Financial Collateral Directive & 2002/47/EC & 06/06/2002 & $27 / 12 / 2003$ & $\begin{array}{l}\text { Harmonized regulation on } \\
\text { financial collateral arrangements }\end{array}$ \\
\hline Prospectus Directive & 2003/71/EC & 06/02/2002 & $31 / 12 / 2008$ & $\begin{array}{l}\text { Harmonized regulation for } \\
\text { financial product prospectuses }\end{array}$ \\
\hline Market Abuse Directive & 2003/6/EC & $28 / 01 / 2003$ & $12 / 10 / 2004$ & $\begin{array}{l}\text { Regulation of insider trading and } \\
\text { market manipulation }\end{array}$ \\
\hline Transparency Directive & 2004/109/EC & $15 / 12 / 2004$ & 20/01/2007 & $\begin{array}{l}\text { Information disclosion } \\
\text { requirements for publicly traded } \\
\text { entities }\end{array}$ \\
\hline $\begin{array}{l}\text { Market in Financial Services } \\
\text { Directive (MiFID) }\end{array}$ & 2004/39/EC & $21 / 04 / 2004$ & $30 / 04 / 2006$ & $\begin{array}{l}\text { Established home country } \\
\text { passport principle for investment } \\
\text { firms }\end{array}$ \\
\hline Payment Services Directive & 2007/64/EC & $13 / 11 / 2007$ & $01 / 11 / 2009$ & $\begin{array}{l}\text { Established the Single European } \\
\text { Payments Area (SEPA) }\end{array}$ \\
\hline \multicolumn{5}{|c|}{ Conjuncture 4. 2007-2012: Financial (dis)integration: The North-Atlantic financial crisis } \\
\hline $\begin{array}{l}\text { Undertakings for collective invest- } \\
\text { ment in transferable securities } \\
\text { (UCITS) }\end{array}$ & 2009/65/EC & $13 / 09 / 2009$ & $01 / 07 / 2011$ & $\begin{array}{l}\text { Regulates collective and retail } \\
\text { investment funds }\end{array}$ \\
\hline $\begin{array}{l}\text { Capital requirements for financial } \\
\text { institutions }\end{array}$ & 2010/76/EU & $24 / 11 / 2010$ & $31 / 12 / 2011$ & Capital requirement reform \\
\hline $\begin{array}{l}\text { Alternative Investment Fund } \\
\text { Directive }\end{array}$ & 2011/61/EU & 08/06/2011 & $22 / 07 / 2013$ & $\begin{array}{l}\text { Regulates non-UCITS investment } \\
\text { funds }\end{array}$ \\
\hline \multicolumn{5}{|c|}{ Conjuncture 5. 2012-2017: Business as usual? } \\
\hline $\begin{array}{l}\text { Market in Financial Services } \\
\text { Directive II (MiFIDII) }\end{array}$ & 2014/65/EU & $15 / 05 / 2014$ & $03 / 09 / 2018$ & $\begin{array}{l}\text { Increase transparency and } \\
\text { investor protection }\end{array}$ \\
\hline $\begin{array}{l}\text { Revised Payment Services Directive } \\
\text { (PSDII) }\end{array}$ & $\begin{array}{l}\text { EU } \\
2015 / 2366\end{array}$ & $25 / 11 / 2015$ & $13 / 01 / 2018$ & $\begin{array}{l}\text { Open banking, financial data } \\
\text { sharing, consumer protection }\end{array}$ \\
\hline
\end{tabular}

Source: Official Journal of the European Union (https://eur-lex.europa.eu/oj/direct-access.html) 
The 1988 Capital Markets Directive was the first major development (Directive 88/361/EEC, transposed 1 July 1990). The directive abolished capital controls and put "freedom of capital" on equal footing to the freedoms of persons and goods enshrined in the 1957 Treaty of Rome. In a bid to become a globally relevant financial power, the directive obliged extending capital freedom beyond the EEC to the rest of the world (Abdelal, 2007; Story \& Walter, 1997). The 1989 Second Banking Directive (Directive 89/646/EEC, transposed 1 Jan 1993) established the passport principle for European banks (Molyneux, 1989; Underhill, 1997). Passporting allows banks to operate in all member states under home central bank supervision based on common standards. The directive was accompanied by the Capital Adequacy Directive (Directive 89/647/EEC, transposed 1 January 1991) that hard-coded Basel I solvency requirements in European law (Mügge, 2006; Underhill, 1997). In this conjuncture, the run-up to monetary union commenced that culminated in the 1992 Maastricht Treaty. (Dyson \& Featherstone, 1999). The prospect of monetary union raised expectations about further future financial integration.

In the early 1980s, member states' financial sectors differed considerably and many financial institutions were lukewarm about Europeanization (Bieling, 2006). A "battle of the systems" (Story \& Walter, 1997) ensued about the financial sector model to be favoured in the Commission's proposals. Ultimately, the Commission championed a system where universal banks played a major role. Universal banks combine the full spectrum of banking services, from retail to investment banking (Jabko, 2006). Large universal banks, particularly those from smaller member states with saturated home markets (Molyneux, 1989), became the Commission's allies in furthering financial integration (Tickell, 1999; Jabko, 2006). Nevertheless, European banks remained ambivalent about EU financial integration. Banking systems consolidated nationally on the retail side (Chick \& Dow, 2012; Dymski. 2012; Leyshon \& Thrift, 1992), while internationalizing in corporate segments such as wholesale banking and securities trading (Larson et al., 2011; Leyshon \& Thrift, 1992; Mügge, 2006). Corporate segments were globalizing rapidly and were regarded as crucial to the future of European banks (Begg, 1992; Llewellyn, 1992). Resultantly, a group of national champion universal banks combining national retail foundations with corporate adventures abroad emerged in the early 1990 s.

\subsection{2-2000: The roaring nineties and the promise of globalization}

Quickly after the 1992 Maastricht Treaty that heralded monetary union, EUphoria relented. The early 1990s recession, combined with monetary turbulence and the steep costs of German reunification, 
gave rise to economic pessimism and an inward focus on immediate national interests (Dicken \& Öberg, 1996; Ross, 1995; Maes, 2007, p. 81). Financial integration plans wound down in tandem (Jabko, 2006, p. 85). The remaining major "1992 directive" (the Investment Services Directive 93/22/EEC; transposed 31 December 1995) was a watered-down comprise (Mügge, 2006). Negotiations failed to reconcile the interests of continental universal banks, the London securities industry (Underhill, 1997) and competing stock exchanges (Bieling, 2003). The directive was an ineffective financial integrator as passporting was based on host country supervision (Wójcik et al. 2007), providing member states leeway to erect non-tariff barriers.

In the early 1990s it was unclear how monetary union would be realized. Although 'Maastricht' committed member states to monetary union, It included provisions for a transition period to complete the internal market, navigate the challenges of reunifying Germany, and achieve macroeconomic convergence (Story \& Walter, 1997, p. 93). Convergence and monetary union were envisaged to evolve in lockstep on the macro level (Dyson, 2002) and indicators of "economic convergence" have since been used as the prime indicator of how Europeanization is progressing (Bassens et al. 2013). However, how this lockstep translated into concrete political action was not immediately self-evident. As the 1990s progressed, the European Commission and financial regulators were increasingly able to convince the public of an imagined future where the Euro and financial integration seemed a fait accompli (Pollard \& Sidaway, 2002).

Monetary union comprised three stages. The first, liberating capital controls, was achieved by 1990. The second stage, in 1994, created the European Monetary Institute (EMI), the precursor to the ECB. The EMI monitored the convergence of European economies, becoming allied to the Commission in promoting the integration project (Jabko, 1999). By 2000, the EMI had succeeded in convincing the European central banks to standardize monetary policy techniques (Braun, 2018). At the Madrid Summit, in December 1995, apart from making a membership overture to the post-socialist countries of Central and Eastern Europe, a date was also set for stage 3 of monetary union. By January 1, 1999, exchange rates were to be fixed and the Eurocurrency born (Mügge, 2006).

It is debatable whether monetary integration was a necessary condition for financial integration and vice versa (Sandholtz, 1993). Regardless, such a co-dependence was emphasized to justify the politics of monetary integration (idem, Bieling, 2006; Jabko, 1999). The prospect of a single currency would decrease cross-border transaction costs (Tickell, 1999), increase industrial transnationalization (McCarthy \& Dolfsma, 2015), and was expected to culminate in consolidation of financial institutions (Dow, 1994). These expectations fed into a bank merger wave in the late 1990s (Bayoumi, 2017, pp. 37-39; Dymski, 2012). The privatization bonanza generated by the '1992 process' and the neoliberal zeitgeist provided significant investment bank jobs for European universal banks. Privatizations 
galvanized European stock markets, which were gearing up for increased competition (Engelen, 2007). As the UK opted out of the Euro, fantasies that other financial centres could compete with London were rife (Beaverstock et al., 2005). Large universal banks used the reinvigorated capital markets for takeovers, preparing to come out on top in what consultants called 'the global end game in banking' (Van Meeteren \& Bassens, 2018), resulting in Europeanization through consolidation (Mulder \& Westerhuis, 2015). Many West-European banks, particularly those with saturated home markets², started expanding in the "emerging markets" of post-socialist Europe (Smith, 2002), especially where eventual EU membership was anticipated (Jöns, 2001; Karreman, 2009; Lindstrom \& Piroska, 2007; Vliegenthart \& Horn, 2007). Resultantly, East-European banking sectors became predominantly foreign owned (Epstein, 2008). Many takeovers were financed on capital markets (Van Meeteren \& Bassens, 2018), stimulating adoption of shareholder capitalism models of corporate governance (Story \& Walter, 1997, p. 156; Wójcik, 2002). Meanwhile, galvanized by promises of the 'new economy', this shareholder model was driving an unprecedented stock market frenzy in the United States (Feng et al., 2001). The dotcom boom fed narratives that Europe was (again) 'staying behind' in new rounds of innovation (Bieling, 2003; Power, 2002) which induced many countries to think more favourably about liberalized stock markets (Bieling, 2003, 2006).

The late 1990s conjured a millennial frenzy, where expectations of radically different futures sent stock markets skyrocketing. During this frenzy, the 'second phase' of financial integration was initiated. The Commission, with significant input from large European financial players (Mügge, 2010), concocted the Financial Services Action Plan (FSAP, COM 1999), a blueprint for a new set of directives intending to Europeanize capital markets (Quaglia, 2010a, pp. 34-35). The FSAP was incorporated in the 2000 Lisbon Agenda as the Europeanized capital market had to enable financing a Europe-wide knowledge-based economy (Maes, 2007, p. 104).

\subsection{0-2007: Europe sinks in the age of market-based banking}

Konings (2008) argues that the 2000 dotcom burst is a watershed moment for European finance. Whereas in the 1990s all financial actors seemed to profit from higher economic tides, after the burst it was predominantly "big finance" that recovered. This partial recovery accelerated the decline of second-tier financial centres (Engelen, 2007) and incentivized widespread adoption of "shareholder value" corporate governance (Wójcik, 2006). The period of relative downturn, until about 2003, was the gestation period of the FSAP directives. The directives were perceived as urgent, as slow recovery was attributed to the sluggishness of Europe in adopting new regulations to accommodate the fast-

\footnotetext{
2 The Belgian bank KBC is exemplary for this trend. The bank eventually became a big player in the Czech Republic, Slovakia, Hungary, Poland and Bulgaria.
} 
changing world of finance (Grahl, 2011). Resultantly, the FSAP directives (Table 1) were established under the new Lamfalussy governance procedure (Quaglia, 2010a) which sped up the policy-making process and made it more transparent, but also formalized private-sector influence and rendered the process more technocratic (Maes, 2007; Mügge, 2011; Posner \& Véron, 2010).

The FSAP moved beyond mere market opening measures and initiated Europe-wide regulation (Quaglia, 2010b). Key FSAP directives in the early 2000s (particularly MiFID, see Table 1) established home-country control for investment services that transformed European capital markets (Wójcik et al., 2007; Macartney, 2009). In 2006, Basel II regulations were translated in revised banking and capital requirements directives (Quaglia, 2008). In 2007, the Payment Services Directive (2007/64/EC, transposed 1 November 2009) established the Single European Payments Area (SEPA) and international accounting standards were enshrined in European regulation (Perry \& Nölke, 2006). Together with clearing initiatives at the ECB, this significantly upgraded the "financial plumbing", clearing and settlement efficiency, of EU finance (Maes, 2007; Quaglia, 2010a).

While some locate the roots of financialization in the 1970s (French et al., 2011), it is in the mid2000s when many of financialization's quintessential characteristics, such as securitization, the rise of repo markets and derivatives, algorithmic trading and shareholder capitalism, really become transformative. An enormous capital glut, a "wall of money" (Engelen et al. 2011), particularly from large institutional investors such as pension funds, incentivized listed corporations to comply with financial market imperatives (Clark and Wójcik, 2007). The FSAP directives allow use of government bonds as collateral, in "repo agreements", stimulating financial institutions to borrow cash to seek high returns on financial markets (Gabor \& Ban, 2015). The resulting infrastructure allows the ECB to transmit monetary policy across the European territory through the inter-bank market (Braun, 2018), contributing to the erosion of "variety in capitalism" (Engelen et al. 2010; Ward et al. 2018) and the distinction between capital- and bank-based financial systems (Hardie \& Howarth, 2013). In the new modus operandi, the savviest banks engaged in "market-based banking" (idem), scouring the world for profit-generating assets to securitize into tradable financial products (Leyshon \& Thrift, 2007; Wainwright, 2015) or trade in these securities. Universal banks made record profits (Engelen et al. 2011, p.113) by benefitting from the favourable conditions enshrined in the EU codification of the Basel II treaty after 2004 (Bayoumi, 2017, p. 86). The coinciding bank merger wave was seen as a sign of economic strength (Wigger, 2012). Moreover, bank lending seemed to flow to those places that were relatively underdeveloped, signalling that that convergence was now finally happening (Bassens et al., 2013). According to European Commissioner Charles McCreevy (2004, p. 2), thanks to the FSAP, there now was "incontrovertible evidence, $[. .$.$] that European markets are beginning to integrate and$ costs are falling". 
McGreevy's sense of progress had its casualties. MiFID enabled "the global stock market" (Wójcik, 2011) because it eliminated legal barriers to financial trade. Resultantly, the deepest markets centralized most trading activity (Wójcik, 2009; 2011), to the detriment of secondary financial sectors (Engelen, 2007; Engelen \& Grote, 2009; Fernandez, 2011). Many mid-sized European banks that had benefitted from the 1990s financial integration could not keep up and lost the "end game" of the bank merger wave (Van Meeteren and Bassens, 2018; see also Mügge, 2010). By 2007, there were 12 megabanks in the Eurozone accounting for the entire increase in assets of the early 2000s (Bayoumi, 2017 , p.39, p. 88). The success of finance dwarfed other goals of the Lisbon agenda, culminating in a financialized rather than a knowledge-based European economy (Birch \& Mykhenko, 2014). Nevertheless, difference in Europe persisted. The new member states had not participated in the policy process (Vliegenthart and Horn, 2007; Quaglia, 2010a) and their financial sectors had fallen prey to majorities of foreign owners. Geographies of banking practices (Hardie and Howarth, 2013) and mortgages (Aalbers, 2009a) remained differentiated across the continent. Particularly in the relative economic periphery (e.g. Italy and Greece), established conservative banking practices such as dependence on government bonds remained common practice (Pagoulatos \& Quaglia, 2013).

\subsection{7-2012: Financial (dis)integration: The North-Atlantic financial crisis}

From the EU perspective, the North-Atlantic financial crisis (Jessop, 2015) has two distinct phases demarcated by the fall of Lehman Brothers in September 2008 (Bassens et al., 2013, p. 2409). The crisis originated in summer 2007, when the US subprime mortgage market melted down (Aalbers, 2009b), resulting in a run on the repo and the securitization-fuelled shadow banking system (Thiemann, 2014). In August 2007, three of BNP Paribas' investment funds terminated redemptions, signalling the start of crisis transmission to Europe (Engelen, 2012). The big universal banks, such as BNP Paribas, Société Générale, Nataxis but also smaller German regional banks (Hendrikse, 2015; Howarth \& Quaglia, 2016) had toxic US mortgages on their balance sheets, acquired in the boom years, triggering obligations they could no longer meet (Bayoumi, 2017; Fligstein \& Habinek, 2014; Jones et al., 2016). As bank supervision was not Europeanized, resolving failures was a member state affair (Howarth \& Quaglia, 2016). After Lehman Brothers, the interbank market froze, prohibiting the short-term refinancing of debt. European convergence indicators started failing (Bassens et al., 2013, see also Figure 2), thus pushing more banks and governments into insolvency. Lenders lost faith in the cracking narrative of a European financial space and began acting as if the EU was merely a loose association of states (idem). This development culminated in a 'deadly embrace' (De Grauwe, 2013; Epstein \& Rhodes, 2016) between banks and sovereigns, where downgrades of government bonds recursively triggered new bank failures. The weaker Southern European economies bore the gravest 
consequences (Lapavistas et al., 2012). Negotiations around subsequent European and IMF bailouts in Greece (April 2010, July 2011), Ireland (November 2010), Portugal, (May 2011), Spain (June 2012), and Cyprus (June 2012) (Howarth \& Quaglia, 2016) formed the backdrop of a frantic European search to reverse the performative narrative of a failing Europe within the margins of its established political power structure.

Given the substantial role of Northern European banks in the genesis and transmission of the crisis, the imaginary guiding the crisis resolution, is remarkable and arguably complacent and false (Engelen et al., 2011; Engelen, 2012). In efforts at resolution, the crisis has consistently been presented as typical to "Anglo-American capitalism" exported like a "cancer" to Europe (Bieling, 2014; Engelen, 2012). This was bad capitalism supposedly kept outside the European "island of stability" (Bassens \& Van Meeteren, 2019). Post-crisis reform therefore focused on building "a wall around Europe" (Pagliari, 2013). Before that wall could be erected, bailouts produced distinctive governance crises unforeseen in the European treaties (Mamadouh \& Van der Wusten, 2013). Jones et al. (2016) label this a "failing forward" period, where member states' reluctance to Europeanize resulted in crippled policies entailing draconic consequences for the member states subject to them. Haggling between member states each wanting to minimize individual exposure to the crisis produced a temporary (May 2010) and eventually permanent (Dec 2012) 500 billion European Stability Mechanism (ESM). However, drawing on this ECB-monitored battle chest came with very thorny strings attached (Epstein \& Rhodes, 2016). The ESM was coupled with new series of regulations, the "six pack" (Sep 2010), the "two pack" (Nov 2011) and the "fiscal compact" (March 2012), which progressively raised member state budgetary requirements and were increasingly punitive toward those failing to meet them (Schmidt, 2015). All these policies would allegedly fix the broken part and jumpstart convergence as represented in borrowing and bond yields, despite the widely diverging social costs across the European continent (Lapavistas et al., 2012; Varoufakis, 2016).

Regarding re-regulating finance, the crisis initially spawned bold regulatory proposals, particularly when addressing the putative Anglo-American practices the crisis was blamed on. For a while, more prudential, less free market-oriented policy proposals were considered (Quaglia, 2012a). In 2009, regulations governing credit rating agencies, deposit guarantees and alternative investment funds were proposed (the UCITS Directive 2009/65/EC, transposed 1 July 2011, see Quaglia, 2012b; Dörry, 2015), although the Alternative Investment Fund Directive was only adopted in 2011 and fully transposed by 22 July 2013 (Directive 2011/61/EU). The priority given to constrain activities of hedge funds in this directive was remarkable. While hedge funds were portrayed as the Anglo-American "locusts" in the European financial space (Engelen, 2012) and were blamed for the downfall of proud European national champions such as ABN AMRO (Van Meeteren \& Bassens, 2018), hedge funds had 
played no role in the financial crisis (Quaglia, 2011). Like the Lamfalussy expert group a decade earlier, the De Larosière (2009) expert group produced a European financial governance overhaul report (Spendzharova, 2012). The eventual De Larosière regulations (see Quaglia, 2012b) encompassed regulation on derivatives (Regulation 648/2012) and strengthened capital requirements for financial institutions (Directive 2010/76/EU, transposed by 31 December 2011). Nevertheless, many proposed banking supervision regulations remained long in limbo (Jones, 2015).

Despite this flurry of regulatory activity, entropy of European financial space continued. Quaglia et al. (2016) report that between 2005 and 2011 cross-border bondholding fell from 40\% to 33\%, disturbing transmission of monetary policy. The future of large (investment) banks seemed clouded (Wójcik, 2012; Wójcik \& MacDonald-Korth, 2015). Moreover, new rounds of sovereign bankruptcies were by now threatening Italy and Eurozone integrity (Mamadouh \& Van der Wusten, 2013). In order to buy time, incoming ECB president Mario Draghi announced on 26 July 2012 (Draghi, 2012) that "the ECB is ready to do whatever it takes to preserve the euro. And believe me, it will be enough". In practice, this meant creating a trillion euros and lending them to banks in exchange for troubled collateral from their books (Jones, 2015; Varoufakis, 2015). This trillion-euro gesture immediately reinstated the representational space of an enduring Europe, and as Jones $(2015$, p. 44$)$ claims, quietly dissolved the sense of urgency to build new crisis-resistant institutions.

\subsection{2-2017: Business as usual? A preliminary analysis of recent events}

The current conjuncture's policy cycle is still ongoing and it is therefore impossible to tell how the European financial space will react to current policy initiatives. We can, however, interrogate the 2012-2017 conjuncture's key representational space: "financial union". According to Epstein and Rhodes (2018), financial union will transform European economic governance in European economic government. Financial union is the outcome of the Five Presidents Report (Juncker, 2015) and the Four Presidents Report (Van Rompuy, 2012) (see Howarth \& Quaglia, 2016, p. 201), which promises that, this time, Europe will move towards a 'genuine economic and monetary union' (title of Van Rompuy, 2012, emphasis added). The Juncker Commission spearheads financial union, which integrates the continuing struggle about banking union with an FSAP-style initiative called Capital Markets Union (CMU) (Epstein \& Rhodes, 2018). Juncker is a veteran of eurocrisis politics (Holmes, 2014) and as former prime minister of Luxemburg, a main beneficiary of a dominant financial sector, optimistically predisposed toward finance's role in renewing European integration (Dörry 2016; Quaglia et al., 2016).

Similar to the FSAP in 1999, optimism generated by the return to normal after the Draghi intervention seems to have invigorated financial lobbying (Engelen \& Glasmacher, 2018; see Braun et 
al. 2018, for overview), including renewed calls for lenience toward securitization (idem, Fernandez \& Aalbers, 2017). Recent directives, MiFID2 (Directive 2014/65/EU, fully transposed 3 September 2018) and PSD2 (Directive EU 2015/2366, transposed 13 January 2018) enable further digitization and platformization of financial services (FinTech). These directives have the potential to change the European financial landscape, but the precise effects on market-based banking and the EU financial sector are still uncertain (Hendrikse et al., 2018). Meanwhile, the boldest of all post-crisis proposals, the financial transaction tax, has been dying a slow death (Gabor, 2016; Kalaitzake, 2017). ECB opposition hastens the death, as the tax would endanger the transmission of monetary policy, which reversed European entropy after Draghi started pumping liquidity into the system (Braun, 2018). The same jubilant representation of space that guided "1992", the Euro and the FSAP, which portrays financial integration as the only available medicine to the illness of alleged economic backwardness is back, projecting a financialized future.

\section{Summary: Relating directives to spatial practice}

Since 1995, the EMI and ECB collect "price based" and "quantity based" statistics measuring convergence in Eurozone financial markets. Price-based indicators measure price convergence in member states' money, bonds, equity and banking market segments. Quantity based statistics measure (since 1999) the increase in cross-border transactions. Although these statistics have their qualifications (ECB, 2017 provides extensive information), they allow for summarizing this paper's argument. Figure 2 shows the degree of convergence of three different indicators, with a score of 1 meaning a full convergence. We use the composite price and quantity statistics based on all four indicators and the equity market price indicator. The vertical lines indicate shocks (red), other events (green), and directives and their transposition periods (blue). The indicators depict whether spatial practices of financial actors have Europeanized. The shocks, events, and directives compose a discursive landscape in which these spatial practices occur.

Figure 2 underlines the gradual EU financial integration chronicled above. Whereas prices on banking, bond and money markets were converging by the millennium, equity prices remained volatile. Equity prices diverge after the dotcom crash and they only start moving in lockstep with the other indicators after the FSAP directives. The volume indicator only starts to converge, first downward then upward, after the collapse of Lehman Brothers when the EU increasingly interferes in bond markets. These observations indicate that European directives, that is laws, have been consequential for shaping EU financial market geographies (Christophers, 2015). Although these consequences occur with a time lag as crisis and volatility followed the new policy packages. Policy proposals, such as the FSAP, are products of specific conjunctures, but implementation and policy effects only become fully apparent 
after that conjuncture has passed. By the time the FSAP directives became law, the context had radically changed, fuelling financial bubbles that were unanticipated in the 1990s.

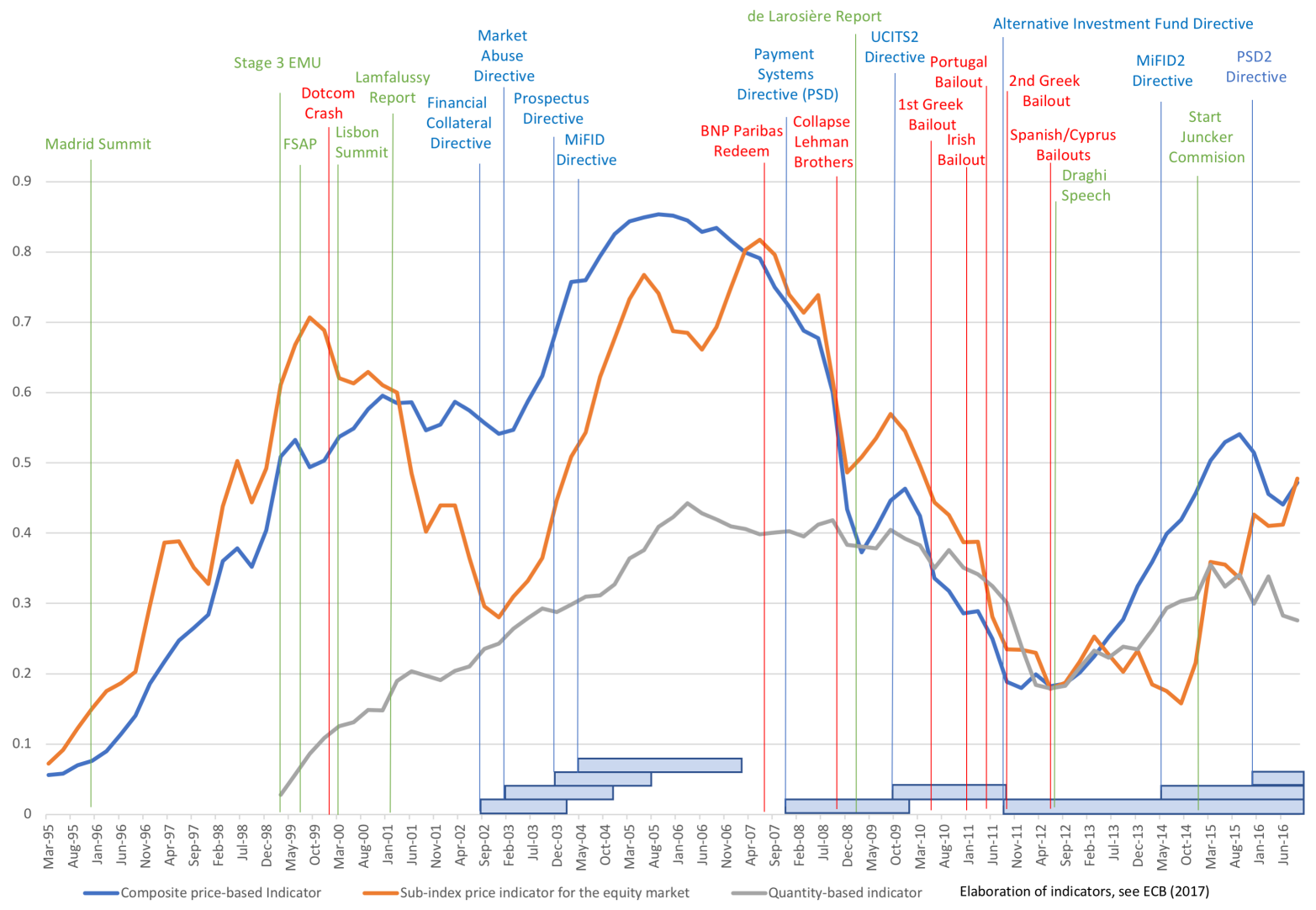

Figure 2. ECB key indicators of financial integration and key events 1995-2016 ${ }^{3}$

\section{Conclusion}

Delors (1992 [1989], p. 155) once said that the "scale of the European Community is inscribed in the natural extension of European financial space", underlining the EU elite's belief how Europeanization is underpinned by an intertwined financial geography of Europe-wide transactions. This paper's prime purpose was to collate the large but disparate interdisciplinary literature on how that European space came to be. An enduring seductive geography of a financially integrated EU, strong enough to be an innovative yet sturdy island of stability, emerges. This imagined future (Beckert, 2016) induces firms to plan mergers and adapt their spatial practices foreseeing change towards this utopia. Anticipating the Euro and the effects of the Draghi's speech are examples of such performativity. Each new round of European financial integration supposedly "shaved away" another layer of geographical difference until the "genuine" EUropean teleological outcome is finally achieved (cf. Matthijs \& Blyth, 2015). Yet beneath this homogenizing discourse, unintended consequences occur as the EU-level developments interact with other domains. For instance, the FSAP did not lead to a European Silicon Valley-style

\footnotetext{
${ }^{3}$ Source: https://www.ecb.europa.eu/stats/financial_markets_and_interest_rates/financial_integration/html/index.en.html
} 
capital market but to consolidation of big European banks. Nevertheless, because the FSAP led to more financial integration it was still considered a success, rendering the completely different causal mechanisms that led to this success invisible. A discursive advantage is that the Silicon Valley style capital market desire could be recycled when negotiating Capital Markets Union (Engelen \& Glasmacher, 2018), perpetuating the teleological narrative.

These examples of interaction effects involving EU financial integration illustrate the purpose of this paper as building block for further research. The EU scale is one element in a varied geographical landscape in which capital is articulated in the concrete (Pickles and Smith, 2016). As the economicgeographical research agenda reconnects to the theme of uneven development amidst macroregional integration (Peck, 2016), better understanding the salient case of the EU is crucial. By organizing the rich literature on financial integration in a common geographical framework, it is hoped that this scale is less elusive for researchers pushing that crucial research agenda.

\section{References}

Aalbers, M. B. (2009a). The globalization and Europeanization of mortgage markets. International Journal of Urban and Regional Research, 33(2), 389-410.

Aalbers, M. B. (2009b). Geographies of the financial crisis. Area, 41(1), 34-42.

Aalbers, M. B. (2018). Financial geography I: Geographies of tax. Progress in Human Geography, 42(6), 916-927.

Abdelal, R. (2007). Capital Rules: The Construction of Global Finance. Cambridge MA: Harvard University Press.

Agnew, J. A., \& Corbridge, S. (1995). Mastering Space. London and New York: Routledge.

Albert, M., \& Ball, R. J. (1983). Towards European Economic Recovery in the 1980s. Report Presented to the European Parliament. European Parliament: Brussels.

Barnes, T. J. (2008). Making Space for the Economy: Live Performances, Dead Objects, and Economic Geography. Geography Compass, 2(5), 1432-1448.

Bassens, D., Van Meeteren, M., Derudder, B., \& Witlox, F. (2013). No more credit to Europe? Crossborder bank lending, financial integration, and the rebirth of the national scale as a credit scorecard. Environment and Planning A, 45(10), 2399-2419.

Bassens, D. \& Van Meeteren, M. (2018). Geographies of finance in a globalizing world. In R. C. Kloosterman, V. Mamadouh \& P. Terhorst (Eds.) Handbook of Geographies of Globalization (pp. 248-257). Cheltenham: Edward Elgar. 
Bayoumi, T. (2017). Unfinished Business. New Haven and London: Yale University Press.

Beaverstock, J. V., Hoyler, M., Pain, K., \& Taylor, P. J. (2005). Demystifying the Euro in European Financial Centre Relations: London and Frankfurt, 2000-2001. Journal of Contemporary European Studies, 13(2), 143-157.

Beckert, J. (2016). Imagined Futures: Fictional Expectations and Capitalist Dynamics. Cambridge MA: Harvard University Press.

Begg, I. (1992). The spatial impact of completion of the EC internal market for financial services. Regional Studies, 26(4), 333-347.

Bieling, H.-J. (2003). Social forces in the making of the new European economy: The case of financial market integration. New Political Economy, 8(2), 203-224.

Bieling, H.-J. (2006). EMU, financial integration and global economic governance. Review of International Political Economy, 13(3), 420-448.

Bieling, H.-J. (2014). Shattered expectations: The defeat of European ambitions of global financial reform. Journal of European Public Policy, 21(3), 346-366.

Bieri, D. S. (2009). Financial stability, the Basel Process and the new geography of regulation. Cambridge Journal of Regions, Economy and Society, 2(2), 303-331.

Birch, K., \& Mykhnenko, V. (2014). Lisbonizing versus financializing Europe? The Lisbon Agenda and the (un)making of the European knowledge-based economy. Environment and Planning C: Government and Policy, 32(1), 108-128.

Braun, B. (2018). Central banking and the infrastructural power of finance: the case of ECB support for repo and securitization markets. Socio-Economic Review. doi: 10.1093/ser/mwy00

Braun, B., Gabor, D. V., \& Hübner, M. (2018). Governing through financial markets: Towards a critical political economy of Capital Markets Union. Competition and Change, 22(1), 101-116.

Brenner, N. (1998). Between fixity and motion: accumulation, territorial organization and the historical geography of spatial scales. Environment and Planning D: Society and Space, $16,459-482$.

Brenner, N. (2004). New State Spaces. Oxford: Oxford University Press.

Brenner, N. (2009). A thousand leaves: Notes on the geographies of uneven spatial development. In R. Keil \& R. Mahon (Eds.), Leviathan Undone? Towards a Political Economy of Scale (pp. 27-51). Vancouver: University of British Columbia Press 
Cassis, Y., \& Wójcik, D. (Eds.). (2018). International Financial Centres after the Global Financial Crisis and Brexit. Oxford: Oxford University Press.

Cecchini, P. (1988) The European Challenge: 1992 - The Benefits of a Single Market. Aldershot: Wildwood House.

Chick, V., \& Dow, S. C. (2012). On causes and outcomes of the European crisis: Ideas, institutions and reality. Contributions to Political Economy, 31, 51-66.

Christophers, B. (2015). The Law's markets: Envisioning and effecting the boundaries of competition. Journal of Cultural Economy, 8(2), 125-143.

Cox, K. R. (1998). Spaces of dependence, spaces of engagement and the politics of scale, or: looking for local politics, Political Geography 17(1), 1-23.

Clark, G. L., \& Wójcik, D. (2007). The Geography of Finance: Corporate Governance in a Global Marketplace. Oxford: Oxford University Press.

Clark, J., \& Jones, A. (2008). The spatialities of Europeanisation: Territory, government and power in "EUrope." Transactions of the Institute of British Geographers, NS33(3), 300-318.

Communication of the Commission (COM) (1985). Completing the internal market: White paper from the Commission to the European Council. Milan: Commission of the European Communities. $\operatorname{COM}(85) 310,14-06-85$

Communication of the Commission (COM) (1999). Financial SErvices: Implementing the Framework for Financial Markets: Action Plan. COM (1999)232, 11.05.99

De Grauwe, P. (2013) Design failures in the Euro zone: Can they be fixed? LSE 'Europe in Question' Discussion paper, 57/2013.

De Larosière, J. (2009) The High-Level Group on Financial Supervision in the EU. Report. Brussels: 25 Feb 2009.

Delors, J. (1992 [1988, 1989]). Le nouveau concert Européen. Paris: Editions Odile Jacob.

Dicken, P., \& Öberg, S. (1996). The global context: Europe in a world of dynamic economic and population change. European Urban and Regional Studies, 3(2), 101-120.

Dixon, A. D. (2011). The geography of finance: Form and functions. Geography Compass, 5(11), 851862. 
Dow, S. (1994). European monetary integration and the distribution of credit availability. In S. Corbridge, N. J. Thrift \& R. Martin. Money, Power, and Space, (pp. 149-64) Oxford: Blackwell Publishers.

Draghi, M (2012) Speech by Mario Draghi, President of the European Central Bank at the Global Investment Conference in London. 26 July 2012.

Dymski, G. A. (2012). Financial mergers and acquisitions. From regulation to strategic repositioning to geo-economics. In D. Faulkner, S. Teerinkangas, \& R. Joseph (Eds.), The Handbook of Mergers and Acquisitions (pp. 566-592). Ofxord: Oxford University Press.

Dyson, K. H., \& Featherstone, K. (1999). The Road to Maastricht: Negotiating Economic and Monetary Union. Oxford: Oxford University Press.

Dyson, K. (2002). Introduction: EMU as integration, Europeanization, and convergence. In K. Dyson (Ed.) European States and the Euro. Europeanization, Variation, and Convergence, (pp. 1-27). Oxford: Oxford University Press.

Dörry, S. (2015). Strategic nodes in investment fund global production networks: The example of the financial centre Luxembourg. Journal of Economic Geography, 15(4), 797-814.

Dörry, S. (2016). The role of elites in the co-evolution of international financial markets and financial centres: The case of Luxembourg. Competition and Change, 20(1), 21-36.

ECB (2017) Financial Integration in Europe. Frankfurt: European Central Bank.

Engelen, E. (2007). 'Amsterdamned'? The uncertain future of a financial centre. Environment and Planning A, 39(6), 1306-1324.

Engelen, E. (2012). Crisis in space: Ruminations on the unevenness of financialization and its geographical implications. In T.J. Barnes, J. Peck \& E. Sheppard (Eds.), The Wiley-Blackwell Companion to Economic Geography (pp. 242-257). Hoboken NJ: Wiley-Blackwell.

Engelen, E., Konings, M., \& Fernandez, R. (2010). Geographies of Financialization in disarray, the Dutch case in comparative perspective. Economic Geography, 86(1), 53-73.

Engelen, E., Erturk, I., Froud, J., Johal, S., Leaver, A., Moran, M, Nilsson, A. \& Williams, K. (2011). After the Great Complacence. Financial Crisis and the Politics of Reform. Oxford: Oxford University Press.

Engelen, E., \& Grote, M. H. (2009). Stock exchange virtualisation and the decline of second-tier financial centres: The cases of Amsterdam and Frankfurt. Journal of Economic Geography, 9(5), 679. 
Engelen, E., \& Glasmacher, A. (2018). The waiting game: How securitization became the solution for the growth problem of the Eurozone. Competition and Change, 22(2), 165-183

Epstein, R. A. (2008). The social context in conditionality: Internationalizing finance in postcommunist Europe. Journal of European Public Policy, 15(6), 880-898.

Epstein, R. A., \& Rhodes, M. (2016). The political dynamics behind Europe's new banking union. West European Politics, 39(3), 415-437.

Epstein, R. A., \& Rhodes, M. (2018). From governance to government: Banking union, capital markets union and the new EU. Competition and Change, 22(2), 205-224.

Feng, H., Froud, J., Johal, S., Haslam, C., \& Williams, K. (2001). A new business model? The capital market and the new economy. Economy and Society, 30(4), 467-503.

Fernandez, R. (2011). Explaining the Decline of the Amsterdam Financial Centre. PhD Thesis: University of Amsterdam.

Fernandez, R., \& Aalbers, M. B. (2017). Capital Market Union and residential capitalism in Europe: Rescaling the housing-centred model of financialization. Finance and Society, 3(1), 32-50.

Fligstein, N. (2000). The process of europeanization. Politique Européenne, 1(1), 25-19.

Fligstein, N., \& Habinek, J. (2014). Sucker punched by the invisible hand: The world financial markets and the globalization of the US mortgage crisis. Socio-Economic Review, 12(4), 637-665.

Fonteyne, W. (2007). Toward a single financial market. In J. Decressin, W. Fonteyne \& H. Faruqee (Eds.), Integrating Europe's Financial Markets (pp. 1-14). Washington DC: International Monetary Fund.

French, S., Leyshon, A., \& Wainwright, T. (2011). Financializing space, spacing financialization. Progress in Human Geography, 35, 798-819.

Gabor, D. (2016). A step too far? The European financial transactions tax on shadow banking. Journal of European Public Policy, 23(6), 925-945.

Gabor, D., \& Ban, C. (2015). Banking on Bonds: The New Links Between States and Markets. JCMS: Journal of Common Market Studies, 54(3), 617-635.

Grahl, J. (2011). The Subordination of European Finance. Competition and Change, 15(1), 31-47.

Hadjimichalis, C. (1994). The fringes of Europe and EU integration. European Urban and Regional Studies, 1(1), 19-29. 
Hadjimichalis, C. (2011). Uneven geographical development and socio-spatial justice and solidarity: European regions after the 2009 financial crisis. European Urban and Regional Studies, 18(3), 254-274.

Hardie, I., \& Howarth, D. (Eds.). (2013). Market-based Banking and the International Financial Crisis. Oxford: Oxford University Press.

Hendrikse, R. P. (2015). The Long Arm of Finance. Exploring the Unlikely Financialization of Governments and Public Institutions. PhD Thesis: University of Amsterdam.

Hendrikse, R. P., Bassens, D., \& Van Meeteren, M. (2018). The Appleization of finance: Charting incumbent finance's embrace of FinTech. Finance and Society, 4(2), 159-180.

Holmes, C. (2014). "Whatever it takes": Polanyian perspectives on the eurozone crisis and the gold standard. Economy and Society, 43(4), 582-602.

Howarth, D., \& Quaglia, L. (2016). The Political Economy of European Banking Union. Oxford: Oxford University Press.

Hudson, R. (2003). European integration and new forms of uneven development: But not the end of territorially distinctive capitalisms in Europe. European Urban and Regional Studies, 10(1), 4967.

Hudson, R. (2004). Conceptualizing economies and their geographies: Spaces, flows and circuits. Progress in Human Geography, 28(4), 447-471.

Illeris, S. (1989). Producer services: The key sector for future economic development? Entrepreneurship \& Regional Development, 1(3), 267-274.

Jabko, N. (1999). In the name of the Market: How the European Commission paved the way for monetary union. Journal of European Public Policy, 6(3), 475-495.

Jabko, N. (2006). Playing the Market. A Political Strategy for Uniting Europe, 1985-2005. Ithaca \& London: Cornell University Press.

Jensen, O. B., \& Richardson, T. (2004). Making European Space: Mobility, Power and Territorial Identity. London and New York: Routledge.

Jessop, B. (2015). Crisis construal in the North Atlantic Financial Crisis and the Eurozone crisis. Competition and Change, 19(2), 95-112.

Jonas, A. E. (1994). The scale politics of spatiality. Environment and Planning D: Society and Space, 12(3), 257-257. 
Jones, E. (2015). The forgotten financial union: How you can have a Euro crisis without a Euro. In M. Matthijs, \& M. Blyth (Eds.). The Future of the Euro (pp. 44-69). Oxford: Oxford University Press. Jones, E., Kelemen, R. D., \& Meunier, S. (2016). Failing forward? The Euro crisis and the incomplete nature of European integration. Comparative Political Studies, 49(7), 1010-1034.

Juncker, J.-C. (2015). Completing Europe's Economic and Monetary Union. Report Issued by the European Commission on 22 June 2015.

Jöns, H. (2001). Foreign banks are branching out: Changing geographies of Hungarian banking, 19871999. In P. Meusburger \& H. Jöns (Eds.), Transformations in Hungary: Essays in Economy and Society, (pp. 65-124). Heidelberg: Physica Verlag.

Kalaitzake, M. (2017). Death by a thousand cuts? Financial political power and the case of the European financial transaction tax. New Political Economy, 22(6), 709-726

Kalaitzake, M. (2018). Central banking and financial political power: An investigation into the European Central Bank. Competition and Change, [online first], http://doi.org/10.1177/1024529418812690

Karreman, B. (2009). Financial geographies and emerging markets in Europe. Tijdschrift voor Economische en Sociale Geografie, 100(2), 260-266.

Konings, M. (2008). European finance in the American mirror: Financial change and the reconfiguration of competitiveness. Contemporary Politics, 14(3), 253-275.

Lapavistas, C., Kaltenbrunner, G., Labrinidis, Lindo, D., Meadway, J, Michell, J, Paincera, J.P., Pires, E., Powell, J, Stenfors, A., Teles, N, \& Vatikiotis, L. (2012). Crisis in the Eurozone. London and New York: Verso.

Larson, M. J., Schnyder, G., Westerhuis, G., \& Wilson, J. (2011). Strategic responses to global challenges: The case of European banking, 1973-2000. Business History, 53(1), 40-62.

Lavery, S., McDaniel, S., \& Schmid, D. (2018). New geographies of European financial competition? Frankfurt, Paris and the political economy of Brexit. Geoforum, 94, 72-81.

Lee, R. (1976). Integration, spatial structure and the capitalist mode of production in the EEC. In R. Lee \& P.E. Ogden (Eds.), Economy and Society in the EEC, Spatial Perspectives, (pp. 11-37). Farnborough: Saxon House.

Lee, R. (2002). "Nice maps, shame about the theory?" Thinking geographically about the economic. Progress in Human Geography, 26(3), 333-355. 
Lefebvre, H. (1991 [1974]). The Production of Space. Oxford UK and Cambridge MA: Blackwell Publishing.

Leyshon, A., \& Thrift, N. J. (1992). Liberalisation and consolidation: The Single European Market and the remaking of European financial capital. Environment and Planning A, 24(1), 49-81.

Leyshon, A., \& Thrift, N. J. (1995). European financial integration: The search for "an island of monetary stability" in the seas of global financial turbulence. In S. Hardy, M. Hart, L. Albrechts \& A. Knos (Eds.), An Enlarged Europe. Regions in Competition, (pp. 109-144). London: Jessica Kingsley Publishers.

Leyshon, A., \& Thrift, N. J. (1997). Money/Space: Geographies of Monetary Transformation. London and New York: Routledge.

Leyshon, A., \& Thrift, N. J. (2007). The capitalization of almost everything: The future of finance and capitalism. Theory, Culture \& Society, 24(7-8), 97-115.

Lindstrom, N., \& Piroska, D. (2007). The politics of privatization and Europeanization in Europe's periphery: Slovenian banks and breweries for sale? Competition and Change, 11(2), 117-135.

Llewellyn, D. (1992). Banking and financial services. In D. Swann (Ed.), The Single European Market and Beyond, (pp. 90-125). London and New York: Routledge.

Macartney, H. (2009). Variegated neo-liberalism: Transnationally oriented fractions of capital in EU financial market integration. Review of International Studies, 35(02), 451-31.

Maes, I. (2007). Half a Century of European Financial Integration: From the Rome Treaty to the 21st Century. Brussels: Mercatorfonds.

Mamadouh, V., \& Van der Wusten, H. (2008). The European level in EU governance: Territory, authority and trans-scalar networks. GeoJournal, 72(1-2), 19-31.

Mamadouh, V., \& Van der Wusten, H. (2013). The European Union in the grip of accumulated governance crises: the euro, the reform efforts, and the public-support dynamics. Eurasian Geography and Economics, 54(2), 162-181.

Matthijs, M., \& Blyth, M. (Eds.). (2015). The Future of the Euro. Oxford: Oxford University Press.

McCarthy, K. J., \& Dolfsma, W. (2015). The Euro and its impact on the number, size, performance and regional spread of European mergers and acquisitions. Regional Studies, 49(8), 1407-1422.

McCormick, J. (2008). Understanding the European Union: A Concise Introduction (4th ed.) Houndmills: Palgrave Macmillan. 
McCreevy, C. (2004). Assessment of the Integration of the Single Market for Financial Services by the Commission. Speech held at the CESR Committee of European Securities Regulations Conference Paris, 6 December 2004.

Milward, A. S. (2000 [1992]). The European Rescue of the Nation-State. London: Routledge.

Molyneux, P. (1989). 1992 and its impact on local and regional banking markets. Regional Studies, 23(6), 523-533.

Moran, M. (1994). The state and the financial services revolution: A comparative analysis. West European Politics, 17(3), 158-177.

Mulder, A., \& Westerhuis, G. (2015). The determinants of bank internationalisation in times of financial globalisation: Evidence from the world's largest banks, 1980-2007. Business History, 57(1), 122-155.

Mügge, D. (2006). Reordering the marketplace: Competition politics in European finance. JCMS: Journal of Common Market Studies, 44(5), 991-1022.

Mügge, D. (2010). Widen the Market, Narrow the Competition. Banker Interests and the Making of a European Capital Market. Colchester: ECPR Press.

Mügge, D. (2011). From pragmatism to dogmatism: European Union governance, policy paradigms and financial meltdown. New Political Economy, 16(2), 185-206.

Pagliari, S. (2013). A Wall Around Europe? The European Regulatory Response to the Global Financial Crisis and the Turn in Transatlantic Relations. Journal of European Integration, 35(4), 391-408.

Pagoulatos, G., \& Quaglia, L. (2013). Turning the crisis on its head: Sovereign debt crisis as banking crisis in Italy and Greece. In I. Hardie, \& D. Howarth (Eds.), Market-based Banking and the International Financial Crisis (pp. 179-200). Oxford: Oxford University Press.

Peck, J., \& Theodore, N. (2007). Variegated capitalism. Progress in Human Geography, 31(6), 731-772.

Peck, J. (2016). Macroeconomic geographies. Area Development and Policy, 1(3), 305-322.

Perry, J., \& Nölke, A. (2006). The political economy of International Accounting Standards. Review of International Political Economy, 13(4), 559-586.

Pickles, J., \& Smith, A. (2016). Articulations of Capital. Chichester: Wiley

Pollard, J. S., \& Sidaway, J. D. (2002). Editorial: Euroland - economic, cultural and political geographies. Transactions of the Institute of British Geographers, NS 27(1), 7-10. 
Posner, E., \& Véron, N. (2010). The EU and financial regulation: Power without purpose? Journal of European Public Policy, 17(3), 400-415.

Power, D. (2002). IT and institutions in the structuring of European finance: Urban impacts. Economic and Industrial Democracy, 23(3), 335-356.

Quaglia, L. (2008). Financial sector committee governance in the European Union. Journal of European Integration, 30(4), 563-578.

Quaglia, L. (2010a). Governing Financial Services in the European Union: Banking, Securities and PostTrading. London: Routledge.

Quaglia, L. (2010b). Completing the single market in financial services: The politics of competing advocacy coalitions. Journal of European Public Policy, 17(7), 1007-1023.

Quaglia, L. (2011). The 'old' and 'new' political economy of hedge fund regulation in the European Union. West European Politics, 34(4), 665-682.

Quaglia, L. (2012a). The 'old' and 'new' politics of financial services regulation in the European Union. New Political Economy, 17(4), 515-535.

Quaglia, L. (2012b). The regulatory response of the European Union to the financial crisis. In R. Mayntz (Ed.), Crisis and Control: Institutional Change in Financial Market Regulation, (pp. 171-196). Frankfurt: Campus,

Quaglia, L., Howarth, D., \& Liebe, M. (2016). The political economy of European capital markets union. JCMS: Journal of Common Market Studies, 54(3), 185-203.

Ross, G. (1995). Jacques Delors and European Integration. Cambridge: Polity Press.

Rovnyi, I., \& Bachmann, V. (2012). Reflexive geographies of Europeanization. Geography Compass, $6(5), 260-274$.

Sadler, D. (1992). Industrial policy of the European Community: Strategic deficits and regional dilemmas. Environment and Planning A, 24, 1711-1730.

Sandholtz, W. (1993). Choosing union: Monetary politics and Maastricht. International Organization, 47(1), 1-39.

Sandholtz, W., \& Zysman, J. (1989). 1992: Recasting the European bargain. World Politics, 42(1), 95128.

Schmidt, V. A. (2015). The forgotten problem of democratic legitimacy. In M. Matthijs, \& M. Blyth, M. (Eds.). The Future of the Euro (pp. 90-116). Oxford: Oxford University Press. 
Smith, N. (1995). Remaking scale: Competition and cooperation in prenational and postnational Europe. In H. Eskelinen \& F. Snickars (Eds.), Competitive European Peripheries (pp. 59-74). Heidelberg: Springer.

Smith, A. (2002). Imagining geographies of the "new Europe": Geo-economic power and the new European architecture of integration. Political Geography, 21(5), 647-670.

Sokol, M. (2013). Towards a "newer" economic geography? Injecting finance and financialisation into economic geographies. Cambridge Journal of Regions, Economy and Society, 6(3), 501-515.

Spendzharova, A. (2012). Is more 'Brussels' the solution? New European Union member states' preferences about the European financial architecture. JCMS: Journal of Common Market Studies, 50(2), 315-334.

Stone Sweet. A., Sandholtz, W., \& Fligstein, N. (Eds.). (2001). The Institutionalization of Europe. Oxford: Oxford University Press.

Story, J., \& Walter, I. (1997). Political Economy of Financial Integration in Europe: The Battle of the Systems. Manchester: Manchester University Press.

Stubb, A. C. G. (1996). A categorization of differentiated integration. JCMS: Journal of Common Market Studies, 34(2), 283-295.

Swyngedouw, E. A. (2004). Globalisation or "glocalisation?" Networks, territories and rescaling. Cambridge Review of International Affairs, 17(1), 25-48.

Taylor, P. J. (1991). A theory and practice of regions: The case of Europes. Environment and Planning D: Society and Space, 9, 183-195.

Thiemann, M. (2014). In the shadow of Basel: How competitive politics bred the crisis. Review of International Political Economy, 21(6), 1203-1239.

Tickell, A. (1999). European financial integration and uneven development. In R. Hudson \& A. M. Williams (Eds.). Divided Europe: Society and Territory, (pp. 63-78). London: Sage.

Underhill, G. R. (1997). The making of the European financial area: Global market integration and the EU Single Market for financial services. In G. Underhill (Ed.), The New World Order in International Finance (pp. 101-123). London: Palgrave Macmillan.

Van Apeldoorn, B. (2002). Transnational Capitalism and the Struggle over European Integration. London and New York: Routledge. 
Van Meeteren, M., \& Bassens, D. (2016). World cities and the uneven geographies of financialization: Unveiling stratification and hierarchy in the world city archipelago. International Journal of Urban and Regional Research, 40(1), 62-81.

Van Meeteren, M., \& Bassens, D. (2018). Chasing the phantom of a 'global end game': The role of management consultancy in the narratives of pre-failure ABN AMRO. In M. Hoyler, C. Parnreiter, \& A. Watson (Eds.), Global City Makers: Economic Actors and Practices in the World City Network (pp 170-191). Cheltenham: Edward Elgar.

Van Rompuy, H. (2012) Towards a Genuine Economic and Monetary Union. Report Issued by the European Council on 5 December 2012.

Varoufakis, Y. (2016). And the Weak Suffer What They Must? Europe's Crisis and America's Economic Future. New York: Nation Books.

Vliegenthart, A., \& Horn, L. (2007). The role of the EU in the (trans)formation of corporate governance regulation in central eastern Europe - The case of the Czech Republic. Competition and Change, 11(2), 137-154.

Wainwright, T. (2015). Circulating financial innovation: new knowledge and securitization in Europe. Environment and Planning A, 47(8), 1643-1660.

Ward, C., Van Loon, J., \& Wijburg, G. (2018). Neoliberal europeanisation, variegated financialisation: Common but divergent economic Trajectories in the Netherlands, United Kingdom and Germany. Tijdschrift voor Economische en Sociale Geografie, 1-[Online first] http://doi.org/10.1111/tesg.12342

Wigger, A. (2012). The political interface of financialisation and the regulation of mergers and acquisitions in the EU. Journal of European Integration, 34(6), 623-641.

Wójcik, D. (2002). Cross-border corporate ownership and capital market integration in Europe: Evidence from portfolio and industrial holdings. Journal of Economic Geography, 2(4), 455-491.

Wójcik, D. (2006). Convergence in corporate governance: Evidence from Europe and the challenge for economic geography. Journal of Economic Geography, 6(5), 639-660.

Wójcik, D. (2009). Geography of stock markets. Geography Compass, 3(4), 1499-1514.

Wójcik, D. (2011). The Global Stock Market: Issuers, Investors, and Intermediaries in an Uneven World. Oxford: Oxford University Press.

Wójcik, D. (2012). The end of investment bank capitalism? An economic geography of financial jobs and power. Economic Geography, 88(4), 345-368. 
Wójcik, D., \& MacDonald-Korth, D. (2015). The British and the German financial sectors in the wake of the crisis: Size, structure and spatial concentration. Journal of Economic Geography 15(5), 10331055.

Wójcik, D., Sidaway, J. D., \& Beaverstock, J. V. (2007). European financial geographies. Growth and Change, 38(2), 167-173. 